\title{
Urinary incontinence and risk factors
}

\author{
Üriner inkontinans ve risk faktörleri
}

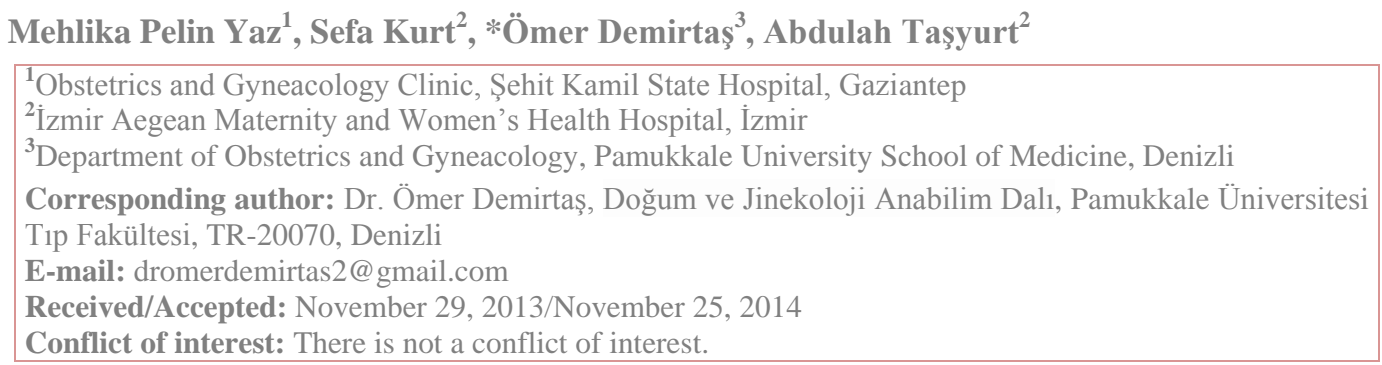

\section{SUMMARY}

Objective: Examining the effects of body mass index (BMI), parity, method of delivery, defects in pelvic floor, diabetes mellitus on the types of incontinence in Urinary incontinence (UI) cases.

Method: 230 UI cases were evaluated in this study. Questions asked to the cases to determine the age, parity and the type of incontinence. Incontinence was diagnosed with history. Additionally, gynecological examination findings, fasting and postprandial blood glucose (FBG-PPG) and hemoglobin A1c(HbA1c) levels were recorded.

Results: The average age was $49.63 \pm 10.68$; gravida $4.21 \pm 2.68$; parity $3.59 \pm 2.51$. The average BMI was determined as $29.86 \pm 4.25$. In $94(40.86 \%)$ of the patients had stress incontinence(SUI), $70(30.43 \%)$ urge incontinence(UUI) and $66(28.69 \%)$ mixed incontinence. Pelvic floor defects was detected at $94(40.86 \%)$ of the cases. Whereas SUI was observed more prominently in juvenile cases with low parity accompanied by anatomic pelvic deformity; the divergence disappears with the introduction of no pelvic floor defect and with 5 or more instances of gestation and delivery. In $114(49.56 \%)$ cases obesity + morbid obesity was existent. In this group, the types of incontinence were similar; in $116(51.44 \%)$ of the cases with normal weight, SUI was more prevalent. It was observed that there was impaired fasting glucose(IFG) in $68(29.56 \%)$ of cases impaired glucose tolerance(IGT) in $49(21.30 \%)$ of cases and diabetes mellitus in $35(15.21 \%)$ of cases. In IGT cases, SUI was more prevalent. UUI was observed more frequently than MUI and SUI in diabetes cases; however the divergence didn't bear any statistical significance $(\mathrm{p}>0.05)$.

Conclusion: SUI is prevalent in juvenile cases with IFG and IGT, low parity and delivery, anatomic defects due to traumatic birth. The divergence disappears with advanced age, high parity and delivery. MUI is observed with advanced age more frequently. UUI is observed more frequently in advanced age patient with DM.

Keywords: Impaired glucose tolerance, urinary incontinence, risk factors

\section{ÖZET}

Amaç: Üriner inkontinanslı hastalarda vücut kitle indeksi, parite, doğum şekli, pelvik taban defektleri ve gizli veya aşikar diabetin inkontinans tiplerinin dağılımı üzerindeki etkisinin araștırılması.

Yöntem: Toplam 230 üriner inkontinans olgusu değerlendirildi. Olgulara; yaş, gebelik, parite, Diabetes Mellitus(DM), gestasyonel diabet ve inkontinans tipini saptamaya yönelik soru formları dolduruldu. Ayrıca boy, kilo, jinekolojik muayene bulguları, açlık-tokluk kan şekeri (AKŞ-TKŞ) ve hemoglobin A1c(HbA1c) ölçümleri değerlendirildi.

Bulgular: Olgularda ortalama yaş 49,63 $\pm 10,68$; gravida 4,21 $\pm 2,68$; parite $3,59 \pm 2,51$; vücut kitle indeksi (VKI) ortalaması 29,86 \pm 4,25 saptanmıştır. Olguların \%40,9'unda (94) stres, \%30,4’ünde (70) urge, \%28,7'sinde (66) mikst inkontinans saptanmıştır. Pelvik taban bozukluğu $94(\% 40,86)$ olguda tespit edildi. Pelvik anatomik bozuklukların eșlik ettiği, genç yaş, düșük parite ve doğumda stres üriner inkontinans (SUI) baskınlığı ön plandayken; pelvik taban defekti olmayan, daha ileri yaş, 5 ve üzeri gebelik ve doğum yapanlarda bu fark ortadan kalkmaktadır; 114 $(\% 49,56)$ olguda obezite + morbid obezite mevcuttu. $68(\% 29,56)$ olguda BAG, $49(\% 21,30)$ 
olguda BGT ve $35(\% 15,21)$ olguda DM tespit edildi. Bozulmuş glukoz toleransı (BGT) saptanan olgularda (SÜI) daha yüksek orandaydı. Diabet saptanan olgularda urge üriner inkontinans (UÜI); mikst (MÜi) ve SÜI'a göre daha fazla saptanmış olmakla birlikte her iki durumda da farklar istatistiksel önemde değildi ( $p>0,05)$.

Sonuç: Düşük parite ve doğum, travmatik doğuma bağlı olabilecek anatomik bozukluk, bozulmuş açlık ve tokluk kan şekeri ve genç yaş SÜI ile ilişkilidir. Daha ileri yaş, yüksek parite ve doğumda gruplar arasında bu fark ortadan kalkmaktadır. İleri yaşla birlikte MÜi daha sık izlenir. UUI ileri yaştaki diabetes mellituslu hastalarda sıktır.

Anahtar sözcükler: Bozulmuş glukoz toleransı, üriner inkontinans, risk faktörleri

\section{INTRODUCTION}

Urinary incontinence (UI) is defined by the International Continence Society (ICS) as: "Involuntary loss of urine which is objectively demonstrable and a social or hygienic problem"1. The hygienic problems and embarrassment, social isolation, depression caused by UI has dire social effects and therefore ICS included these factors within the definition of urinary incontinence ${ }^{2,3}$. UI is commonly a health issue regarding women but it is also observed in men. According to the findings of a research on public based studies, UI frequency was 4.8-58.4\% among women and 1-34.1\% among men ${ }^{4}$. There are many causes constituting a predisposition to urinary incontinence. The main causes are gender, advanced age, pregnancy, delivery, smoking, obesity, constipation and other causes that increase the abdominal pressure. Diabetes Mellitus (DM) is the most common metabolic condition that accompanies UI. It is reported that prior to DM advancement, impaired glucose tolerance (IGT) increases the risk of vascular retention and neuropathy which lead to incontinence ${ }^{5,6}$.

This study aims to determine the effects of age, BMI, pregnancy, birth, delivery method, anatomic pelvic deformity, diabetes, IGT and HbA1c levels on types of incontinence through the study of 230 cases that consulted İzmir Aegean Maternity and Gynecological Diseases Research Training Hospital with UI complaints.

\section{MATERIALS AND METHODS}

Between 15 October 2009-31 January 2011, 8400 patients who applied to the gynecology polyclinic were determined. Among 1540 patients who were not pregnant, married and older than 25, 345 of them had UI complaints and these were taken under evaluation. UI incidence was determined as $22.40 \%$.

The socio-demographic features (age, parity, delivery method) was determined by the same researcher through face-to-face interviews. Questions were asked to ascertain the incontinence type with their general medical queries and their gynecological complaints. Written and verbal consent was acquired for the cases involved in the research. Among 345 with UI, 230 of the cases who fit our study criteria constituted our research group. The inclusion criteria was specified as being older than 25 and married, not having undergone urogynecologic operation or hysterectomy, having no genital malignancy history, not having received radiotherapy or chemotherapy, not having active genitourinary infections, not having prior UI diagnosis and not having taken medication or medically treat cause UI. The exclusion criteria was determined to be such conditions as being under 25 and unmarried, being pregnant during any stage of the study, not being willing to partake in the research or avoiding communication. The height, weight and abnormal gynecological examination results were recorded. Besides the existence of DM; FBG-PPG and HbA1c measurements were taken, normal and abnormal findings were recorded. BMI was determined according to classifications by the World Health Organization. FBG; blood samples taken after a minimum of 8 hours of fasting were examined. In accordance with American Diabetes Association 2004 (ADA 2004) classifications, cases were examined under 3 categories as normal, IFG and DM. PPG was determined by examining the 2 hour postprandial blood samples. Cases which yielded 140-199 mg/dL blood sugar in 2 hour postprandial test results were referred 
to internal diseases ward for OGTT to confirm IGT diagnosis.

Throughout the research "SUI" was assumed as instances of women experiencing involuntary escape of urine during laughter, coughing, lifting heavy objects, "UUI" was assumed as instances of women unable to make it to the bathroom in time and experiencing involuntary escape of urine. MUI was assumed as the presence of both UUI and SUI symptoms. The abnormal examination results were defined without scaling as"cystocele","rectocele", "cystorectocele" and "uterine prolapse".

Normal distribution and homogenity of variance was examined by kolmogrov simirnov test and levene test for quantitative data. Parametric tasts were used in the analysis parametric data had normal distribution. Otherwise, non-parametric tests were used. Independent t-test, one-way anova, tukey, games-howell tests were used in binary comparison of independent groups, comparisons between multiple groups, difference between groups with homogenous variance and difference between groups with nonhomogenous variance, respectively. For nonparametric methods; Mann-Whitney U, KruskalWallis $\mathrm{H}$, nonparametric Tukey tests were used in comparison of independent groups, comparisons between multiple groups and difference between groups respectively. Chi-square and fisher exact tests are used in the comparison of categorical data. Quantitative data were represented as, median, standard deviation and minimummaximum values. Categorical data were expressed as $\mathrm{n}$ (number) and percentage $(\%)$. Results were represented at $95 \%$ confidence level and p-value $<0.05$ was considered significant.

\section{RESULTS}

It was determined that in 230 UI diagnosed cases the age range was $25-80$ and average age was $49.63 \pm 10.68$; average gravida was $4.21 \pm 2.68$ and average parity was $3.59 \pm 2.51$. Medial BMI fell onto the upper-limit of overweight by $29.86 \pm 4.25$ (Table 1).

Table 1: Mean age, gravidity, parity, BMI of the cases.

\begin{tabular}{l|cccc}
\hline & Age & Gravida & Parity & BMI \\
\hline Mean & $49.63 \pm 10.68$ & $4.21 \pm 2.68$ & $3.59 \pm 2.51$ & $29.86 \pm 4.25$
\end{tabular}

SUI constituted the most commonly detected incontinence type with 90 (40.87\%) cases. This was respectively followed by UUI with $70(30.43 \%)$ cases and MUI with $66(28.69 \%)$ cases (Table 2). In our study, the average age of cases were 51.44 for MUI; 50.80 for UUI and 47.49 for SUI. We found the average age for MUI and UUI to be higher than that of SUI with statistical relevance $(p<0.05)$. Whereas, in cases under 30 years of age and between the ages of 30-50 with incontinence highest incidences of SUI was observed; in cases above 50 UUI and MUI was observed more frequently and this increase bears statistical significance $(\mathrm{p}<0.05)$ (Table 2).

Table 2: Distribution of the incontinence types by age.

\begin{tabular}{l|cccc}
\hline Age & Mixed n (\%) & Stress n (\%) & Urge n (\%) & p value \\
\hline$<30$ & $3(33.33)$ & $4(44.44)$ & $2(22.22)$ & nd \\
$30-50$ & $27(22.88)$ & $61(51.69)$ & $30(25.42)$ & nd \\
$>50$ & $36(34.95)$ & $29(28.15)$ & $38(36.89)$ & $<0,05$ \\
\hline Total & $\mathbf{6 6}(\mathbf{2 8 . 6 9 )}$ & $\mathbf{9 4}(\mathbf{4 0 . 8 7})$ & $\mathbf{7 0}(\mathbf{3 0 . 4 3})$ & \\
\hline
\end{tabular}

Table 3. Mean of the body mass index on the type of incontinence.

\begin{tabular}{l|cccc}
\hline & Mixed & Stress & Urge & p value \\
\hline $\begin{array}{l}\text { Mean of } \\
\text { VKI }\end{array}$ & $29.56 \pm 4.48$ & $29.81 \pm 4.35$ & $30.22 \pm 3.91$ & nd \\
\hline
\end{tabular}

The average BMI for the patients was determined as $29.86 \pm 4.25$. No relevant divergence in terms of incontinence types were found in obese + morbid obese group which make up of $49.56 \%$ of all cases with 114 cases ( $>0.05)$ (Table 3). However, SUI incidence was much higher in 116 $(50.43 \%)$ normal weight cases with statistical significance $(\mathrm{p}<0.05)$.No statistically relevant divergence was determined between parity and gravida averages and incontinence types $(p>0.05)$. SUI incidences were higher in those who gave 1-2 
or 3-4 births with statistical significance $(\mathrm{p}<0.05)$; whereas the distribution of incontinence types among those who gave birth 5 or more times was similar (Table 4).

Table 4. The relationship between the number of parity and types of incontinence.

\begin{tabular}{l|cccc}
\hline Parity (n) & Mixed n (\%) & Stress n (\%) & Urge n (\%) & p value \\
\hline 0 & 0 & $2(40.00)$ & $3(60.00)$ & nd \\
$1-2$ & $23(25.55)$ & $42(46.66)$ & $25(27.77)$ & nd \\
$3-4$ & $28(32.55)$ & $33(38.37)$ & $25(29.06)$ & nd \\
$>5$ & $15(30.61)$ & $17(34.69)$ & $17(34.69)$ & nd \\
\hline
\end{tabular}

In $211(91.73 \%)$ of cases the method of birth was normal vaginal birth and in 14 $(6.08 \%)$ the method was caesarean section. Both in vaginal and caesarean section births SUI incidences were higher than MUI and UUI, yet this divergence was not statistically significant. Looking at the gynecological examinations of the cases, while in $136(59.13 \%)$ of the cases the pelvic floor was evaluated as normal; in 94 $(40.87 \%)$ of the cases, anatomic defects as cystocele in $51(22.17 \%)$, rectocele in 4 $(1.73 \%)$, cystorectocele in $34(14.78 \%)$, uterine prolapse in $5(2.17 \%)$ was detected. Cystocele constituted the majority of anatomic defects. SUI incidences were higher in cases with cystocele with statistical significance $\quad(\mathrm{p}<0.05) \quad($ Table 5)

Table 5. The relationships between incontinence types and fasting and postprandial glucose levels and the presence of cystocele.

\begin{tabular}{|c|c|c|c|c|}
\hline & & Mixed n (\%) & Stress n (\%) & Urge n (\%) \\
\hline \multicolumn{5}{|c|}{ FBG } \\
\hline & Normal & $35(27.55)$ & $56(44.09)$ & $36(28.34)$ \\
\hline & IFG & $20(29.41)$ & $27(39.70)$ & $21(30.88)$ \\
\hline \multicolumn{5}{|c|}{ PBG } \\
\hline & Normal & $43(27.38)$ & $64(40.76)$ & $50(31.84)$ \\
\hline & IGT & $16(32.65)$ & $21(42.85)$ & $12(24.48)$ \\
\hline \multicolumn{5}{|c|}{ The presence of cystocele } \\
\hline & Positive & $12(18.18)$ & $31(32.97)$ & $13(18.57)$ \\
\hline & Negative & $54(81.82)$ & $63(67.03)$ & $57(81.43)$ \\
\hline Normal vaginal birth & & $63(29.16)$ & 88 (40.74) & $65(30.09)$ \\
\hline Caesarean section & & $3(21.42)$ & $6(42.85)$ & $5(35.71)$ \\
\hline Incontinence types & & 66 (28.69) & $94(40.86 \%)$ & $70(30.43 \%)$ \\
\hline Incontinence types at diabetic cases & & $11(31.42)$ & $11(31.42)$ & $13(37.14)$ \\
\hline
\end{tabular}

It was determined that the average FBG of 230 cases was $107.31 \mathrm{mg} / \mathrm{dL}$; the average PPG was $134.78 \mathrm{mg} / \mathrm{dL}$ and $\mathrm{HbA1c}$ average was 6.41 (Table 6).

Table 6. The mean oft he blood glucose and HbA1c.

\begin{tabular}{l|ccc}
\hline & FBG & PBG & HbA1c \\
\hline Mean & 107.31 & 134.78 & 6.41 \\
\hline
\end{tabular}

Among 230 cases that formed our research group, $127(55.21 \%)$ of them had normal FBG, 157 (68.26\%) of them had normal PPG measurements. On the other hand, in $68(29.56 \%)$ cases IFG, in $49(21.30 \%)$ cases IGT and in $35(15.21 \%)$ cases DM was detected. In our research, FBG average was higher in MUI with 112.41 $\mathrm{mg} / \mathrm{dL}$ than in SUI $(103.35 \mathrm{mg} / \mathrm{dL})$ and UUI $(107.83 \mathrm{mg} / \mathrm{dL})$ but this divergence did not bear statistical significance ( $p>0.05)$. SUI incidences were determined to be higher in IFG cases, yet this divergence did not bear statistical significance $(p>0.05) \quad($ Table 5). PPG averages of cases were; $145 \mathrm{mg} / \mathrm{dL}$ in MUI, $130 \mathrm{mg} / \mathrm{dL}$ in SUI, $131 \mathrm{mg} / \mathrm{dL}$ in UUI; however this divergence was not determined to be statistically relevant $(p>0.05)$. Stress incontinence incidences were higher in patients with IGT but the divergence is not statistically significant (p>0.05) (Table 5). 
In cases with DM, UUI incidences were higher than that of MUI and SUI, yet this divergence did not bear any statistical significance $(p>0.05)$. The average $\mathrm{HbA} 1 \mathrm{c}$ of 230 cases was determined as $6.41 \pm 1.08$ and this value is higher than the normal range (4-6) of HbA1c (Table 6). HbA1c levels in MUI cases were higher compared to SUI and UUI cases with statistical significance $(\mathrm{p}<0.05)$.

\section{DISCUSSION}

We determined the UI incidence as $22.40 \%$ in our research group. Examining the UI type dispersion, it is observed that in $94(40.86 \%)$ of the cases SUI, in 70 $(30.4 \%)$ of the cases UUI, in $66(28.7 \%)$ of the cases MUI was detected. The most common incontinence type was determined to be SUI and this concurred with the literature ${ }^{7,8}$. Kök et al. ${ }^{9}$ report the incidences of UI in a group of 229 women over the age of 20 as $37.1 \%$; SUI $40.0 \%$; MUI $36.5 \%$; UUI $15.3 \%$ as the results of their study.

SUI incidences were found to be higher in cases with incontinence under the age of 30 and between the ages 30-50. In ages 50 and up, UUI and MUI incidences were observed to be higher. Minassian et al. ${ }^{4}$ in their study, report that SUI prevalence peeks in the 4. decade; whereas UUI and MUI prevalence peeks after the 6 . decade.

The average BMI of all the cases in our study was determined to be $29.86 \pm 4.25$. $114(49.56 \%)$ of the cases was in the obese + morbid obese category. It is reported that UI risk is increased with obesity and continence is significantly related to $\mathrm{BMI}^{10-12}$.

Gynecological examination of 136 $(59.13 \%)$ cases yielded normal results. Among cases with pelvic anatomic defects; the most prevalent defect was cystocele and among those patients with cystocele and incontinence; SUI was observed in 31 $(33.33 \%)$ of them. The positive relevance between cystocele and SUI was found to be statistically significant and the result is in accordance with the literature. $(\mathrm{p}<0.05)^{13-15}$.

The loss in the support of urethra and cervix vesicae can be affiliated with the loss (for example a paravaginal defect) or the loosening of (for example the change in type, amount or quality of collagen in levator fascia) endopelvic fascia, as well as the denervation with tonus loss in the levitor ani muscles (for example instances associated with delivery trauma on the vagina $)^{16,17}$. When the vaginal biopsies taken from the periurethral areas of women with and without premenopausal stress incontinence, it was shown that in the SUI group collagen amounts were less and there were changes in the type $1 / 3$ rate and reduction in the collagen cross linking ${ }^{18}$. $1.30 \%(3 / 230)$ of the patients in our research group did not have a pregnancy history. Approximately half of the cases with 1-2 or 3-4 pregnancies had SUI. After 5 pregnancies, the divergence disappeared and 3 incontinence types were distributed similarly. The prominent prevalence of SUI in patients who were pregnant 1 or 2 times, leads to the reasoning that the factors that cause the deficiencies occur in the first pregnancy and progresses irreversibly. Parazzini et al. ${ }^{19}$ in their research about incontinence types aimed especially at determining incontinence types in women who went through caesarean section, report that the SUI rate was $9 \%$ in the period following caesarean section delivery. This result supports the theory that full-term pregnancy alone can be the cause for UI. Vikki et al. ${ }^{20}$ in their polycentric study involving 1004 cases, studying the effects of full-term pregnancy and delivery method on urinary and fecal incontinence, report that pregnancy alone can increase the risk of UI and fecal incontinence; yet comparing c-section and vaginal delivery, they reported that $\mathrm{c}$ section does not reduce the risk of UI compared to vaginal delivery.

The 230 cases with incontinence in our study, has an average FBG of 107.31; average PPG of 134.78 which are values above normal. High FBG values were detected in $103(44.78 \%)$ of the cases and high PPG values were detected in 73 $(31.73 \%)$ of the cases. The highest FBG, PPGE, HbA1c average was observed in MUI. The highness in HbAlc is statistically relevant as well and this result leads to the reasoning that long term bad 
glycemic control, deterioration in detrusor functions affiliated with microvascular injury and neural innervation defects set ground for MUI. Jeanette et al. ${ }^{21}$ detected Type 2 DM in $17 \%$ and IFG in $11 \%$ of the the incontinence cases. While the SUI and UUI prevalence in normoglycemic cases were $16.8 \%$; they detected similar high rates in Type $2 \mathrm{DM}$ cases with $35.4 \%$ and IFG cases with $33.4 \%$ of incontinence cases. Compared to non-diabetic cases, in diabetic and pre-diabetic cases UI prevalence is 3 times higher in UUI and 2 times higher in SUI.

In $15.21 \%$ of the cases DM was existent and the incontinence types in these cases were monitored in similar rates. DM is an independent risk factor for UI and increases the UI risk 2.5-fold ${ }^{14}$.

In conclusion; the UI incidence in our research group is $22.40 \%$ and the most prevalent UI type is SUI with $40.86 \%$. While in the presence of predisposing factors such as young age, pelvic anatomic defects, first pregnancy and delivery SUI is predominant; in cases with advanced age, without pelvic floor defects, 5 or more pregnancies and deliveries this divergence disappears. The predominance of SUI in first pregnancies, the etiology of which being pelvic floor deficiency, supports the hypothesis that suggests pregnancy can constitute a risk factor independent from delivery. Additionally, the prominent prevalence of SUI in cases with 1 or 2 pregnancies, leads to the reasoning that the factors which cause the deficiencies occur in the first pregnancy and progresses irreversibly. However, new studies are required to thoroughly shed light on pregnancy pelvic relaxation mechanism (collagen amount, nerve denervation etc.).

In incontinent cases, high levels of FBG in $103(44.8 \%)$ and high levels of PPG in 73 $(31.7 \%)$ were detected. The highest FBG, PPG, HbA1c average was observed in MUI. No statistically significant divergence in terms of incontinence types was observed in incontinent patients with IFG, IGT and DM.

$\mathrm{UI}$ is a health problem that reduces the life quality of women and limits social life. It is also a big financial burden for the national economy in effective treatment cost analysis. Therefore, it is important for studies directed at understanding the causes and results of urinary incontinence to become more widespread and it is crucial that preventative-protective health care systems are improved.

\section{REFERENCES}

1. Abrams P, Blavias JG, Stanton SL, Andersen JT. The standardization ofterminology for lower urinary tract function. Br J Obstet Gynaecol 1990; 97: 1-16.

2. Hunskaar S, Sandvik H. One hundred and fifty men with urinary incontinence. III. Psychosocial consequences. Scand J Prim Health Care 1993; 11: 193-6.

3. Lawson JO. Pelvic anatomy. I. Pelvic floor muscles. Ann R Coll Surg Engl 1974; 54: 244-52.

4. Minassian VA, Drutz HP, Al-Badr A. Urinary incontinence as a worldwide problem. Int $\mathrm{J}$ Gynaecol Obstet 2003; 82: 327-38.

5. Kumbasar AB: Impaired glucose tolerance, impaired fasting glucose. Ed: Altuntaş Y, Yenigun M: All Aspects of Diabetes Mellitus. 2001; 236-45.

6. Devore EE, Townsend MK, Resnick NM, Grodstein F. The epidemiology of urinary incontinence in women with Type 2 diabetes. J Urol 2012; 188: 1816-21.

7. Ozerdogan N, Beji NK, Yalcin O. Urinary incontinence: Its prevalence, risk factors and effects on the quality of life of women living in a region of Turkey. Gynecol Obstet Invest 2004; 58: 145-50.

8. Maral I, Ozkardes H, Peskircioglu L, Bumin MA. Prevalence of stress urinary incontinence in both sexes at or after age 15 years: A cross-sectional study. J Urol 2001; 165: 408-12.

9. Kök G, Şenel N, Akyüz A. The evaluation of the awareness level for urinary incontinence in women over 20 years old who refer to GATA gynecology outpatient clinic. Gulhane Medical Journal 2006; 48: 132-6. 
10. Burgio KL, Matthews KA, Engel BT. Prevalence, incidence and correlates of urinary incontinence in healthy, middle-aged women. J Urol 1991; 146: 1255-9.

11. Subak LL, Richter HE, Hunskaar S. Obesity and urinary incontinence: Epidemiology and clinical research update. J Urol. 2009; 182: 2-7.

12. Burti JS, Santos AM, Pereira RM, Zambon JP, Marques AP. Prevalence and clinical characteristics of urinary incontinence in elderly individuals of a low income. Arch Gerontol Geriatr 2012; 54: 42-6.

13. Bruce RG, El-Galley RE, Galloway NT. Paravaginal defect repair in the treatment of female stress urinary incontinence and cystocele. Urology 1999; 54: 647-51.

14. Izci Y, Topsever P, Filiz TM, Cinar ND, Uludağ C, Lagro-Janssen $\mathrm{T}$. The association between diabetes mellitus and urinary incontinence in adult women. Int Urogynecol J Pelvic Floor Dysfunct 2009; 20: 947-52.

15. Dass AK, Lo TS, Khanuengkitkong S, Tan YL. Diagnosis and conservative management of female stress urinary incontinence. Gynecology and Minimally Invasive Therapy, In Press, Corrected Proof, Available online 2013.

16. Ashton-Miller JA, Howard D, De Lancey JO. The functional anatomy of the female pelvic flor and stres continence control system. Scand J Urol Nephrol suppl 2001; 207: 1-7.

17. Leijonhufvud A, Lundholm C, Cnattingius S, Granath F, Andolf E, Altman D. Risks of stress urinary incontinence and pelvic organ prolapse surgery in relation to mode of childbirth. American Journal of Obstetrics and Gynecology 2011; 204: 71-7.

18. Keane DP, Sims TJ, Abrams P, Bailey AJ. Analysis of collagen status in premenopausal nulliparous women with genuine stres incontinence. Br J Obstet Gynaecol 1997; 104: 994-8.
19. Parazzini F, Colli E, Origgi G. Which women with stres incontinence require urodynamic evaluation? Am J Obstet Gynecol 2001; $184 ; 20-7$.

20. McKinnie V, Swift SE, Wang W, Woodman P, O'Boyle A, Kahn M, Valley M, Bland D, Schaffer J. The effect of pregnancy and mode of delivery on the prevalence of urinary and fecal incontinence. American Journal of Obstetrics and Gynecology 2005; 193; 512-7.

21. Doshi AM, Van Den Eeden SK, Morrill MY, Schembri M, Thom DH, Brown JS. Women with diabetes: Understanding urinary incontinence and help seeking behavior. J Urol 2010; 184: 1402-7. 